EESTI NSV TEADUSTE AKADEEMIA TOIMETISED. 28. KOIDE KEEMIA. 1979, NR. 2

ИЗВЕСТИЯ АКАДЕМИИ НАУК ЭСТОНСКОИ ССР. ТОМ 28 ХИМИЯ. 1979, № 2

\title{
КОЛИЧЕСТВЕННОЕ ОПРЕДЕЛЕНИЕ ЦИАНИСТОГО ВОДОРОДА ПРИ ПИРОЛИЗЕ СИНТЕТИЧЕСКИХ ВОЛОКОН
}

Eha URBAS, E. KOLLIK. SUNTEETILISTES KIUDUDES SISALDUVA TSUAANVESINIKU KVANTITA. TIIVNE MAARAMINE PUROLOUSIMEETODIL

Eha URBAS, E. KOLLIK. QUANTITATIVE DETERMINATION OF HYDROGEN CYANIDE IN PYROLYSIS OF SYNTHETIC FIBRES

\section{Представлена О. Эйзеном}

При использовании в быту синтетических материалов, в том числе огнестойких и термостойких волокон, встает вопрос об их вредности для окружающей среды при пожаре и перегревах. Хотя огнестойкие и термостойкие волокна являются трудновоспламеняющимися, при высоких температурах разложение их значительно $\left[{ }^{1-3}\right]$. При термической деструкции из азотсодержащих волокон выделяется достаточно большое
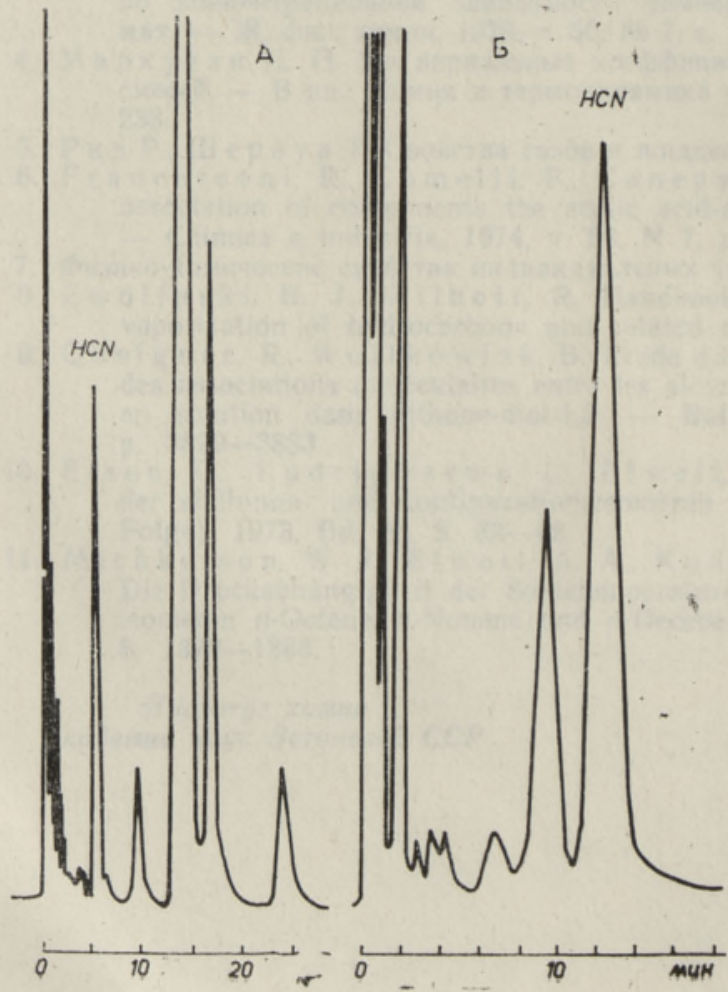
количество цианистого водорода, концентрация которого в закрытом помещении может оказаться смертельно опасной для человека.

Для оценки количества выделяемого $\mathrm{HCN}$ очень удобен и быстр метод пиролизной ГХ.

В данной статье излагается методика определения и разделения $\mathrm{HCN}$ в сложных смесях продуктов пиролиза и приво-

Рис. 1. Газохроматографическое разделение $\mathrm{HCN}$ : $A-$ пирограмма акрилана при $750^{\circ} \mathrm{C}$ (время пиролиза $10 c$, колонка из нерж. стали 2 м Х 2 мм, тверд. носитель инертон $A W \mathrm{c}$ $5 \%$ диметилсульфолана, темп. колонки $\left.20^{\circ} \mathrm{C}\right) ; \bar{B}-$ пирограмма модакрилика при $700^{\circ} \mathrm{C}$ (время пиролиза $12 c$, колонка из нерж. стали 1,3 м Х 2 м.м, носитель порапак $T, 100-$ 120 меш., темп, колонки $\left.70^{\circ} \mathrm{C}\right)$. 
Характеристика колонок для определения цианистого водорода

\begin{tabular}{|c|c|c|c|c|c|c|}
\hline Колонка & $\begin{array}{c}\text { Твердый } \\
\text { носитель, } \\
\text { меш. }\end{array}$ & $\begin{array}{c}\text { Ста- } \\
\text { цио- } \\
\text { нарная } \\
\text { фаза, } \\
\%\end{array}$ & $\underset{M}{\text { Длина, }}$ & $\begin{array}{l}\text { Диа- } \\
\text { метр, } \\
\text { мм }\end{array}$ & $\begin{array}{l}\text { Tем- } \\
\text { пера- } \\
\text { тура, } \\
{ }^{\circ} \mathrm{C}\end{array}$ & $\begin{array}{l}\text { Мате- } \\
\text { риал }\end{array}$ \\
\hline Порапак $Q$ & $80-100$ & - & 1 & 1 & 70 & стекло \\
\hline Порапак $T$ & $100-120$ & - & 1,3 & 2 & 70 & нерж. \\
\hline $\begin{array}{l}\text { Хромосорб } W / 1,2,3 \text {-триэтокси- } \\
\text { нитрилпропан }\end{array}$ & $80-100$ & 7 & 2 & 1 & 40 & стекло \\
\hline Хромосорб $W /$ карбовакс $20 \mathrm{M}$ & $80-100$ & 7 & 2 & 1 & 40 &,-- \\
\hline Хромосорб $W /$ триацетин & $80-100$ & 7 & 4 & 4 & 40 & $-"$, \\
\hline Инертон $A W /$ диметилсульфолан & $80-100$ & 5 & 2 & 2 & 20 & $\begin{array}{l}\text { нерж. } \\
\text { сталь }\end{array}$ \\
\hline
\end{tabular}

дятся результаты определения выделившегося из термостойких волокон HCN в зависимости от температуры. В опытах мы пользовались пиролизатором Дзержинского ОКБА, который был присоединен к хроматографу фирмы «Перкин-Эльмер» (США). Условия пиролиза: скорость газа-носителя (Не) $30 \mathrm{~m} / \mathrm{muн}$, время $12 \mathrm{c}$, температура от 400 до $900^{\circ} \mathrm{C}$, проба $0,2-0,5$ мг.

Для определения $\mathrm{HCN}$ подходят многие широко используемые колонки (таблица). Можно работать и с пламенно-ионизационным детектором, и с катарометром. С первым нами получена чувствительность 0,0007 мка, со вторым она в 500 раз ниже [ $\left.{ }^{4}\right]$. При пиролизе образуется целый ряд летучйх продуктов, что затрудняет газохроматографическое разделение $\mathrm{HCN}$. Оптимальными для разделения пиролизных продуктов оказались колонки с порапаком $T$ и инертон $A W$ с $5 \%$ диметилсульфолана (рис. 1).

Для построения калибровочных кривых (рис. 2) использовался чистый $\mathrm{HCN}$, который смешивался в литровых колбах до определенных концентраций с воздухом [5] и затем смесь вводилась в хроматограф газовым шприцем фирмы Гамильтон. Площади пиков рассчитывались при помощи интегратора.

В целях количественного определения $\mathrm{HCN}$ исследовались азотсодержащие термостойкие химические волокна. На рис. 3 приведены пирограммы кевлара при пяти температурах. Выделение $\mathrm{HCN}$ в заметных количествах начинается при $600^{\circ}$; его объем при $700^{\circ}$ составляет 2,2 и при $900^{\circ}-3,5 \%$ от массы пробы.

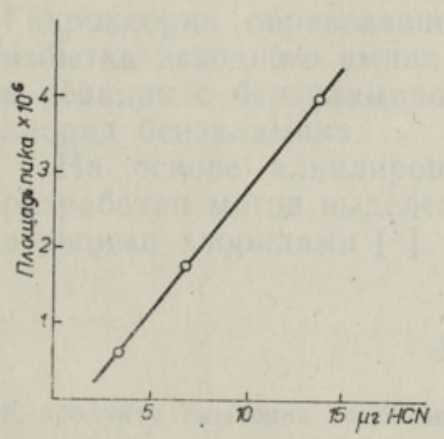

Рнс. 2. Калибровочная кривая для определения $\mathrm{HCN}$.

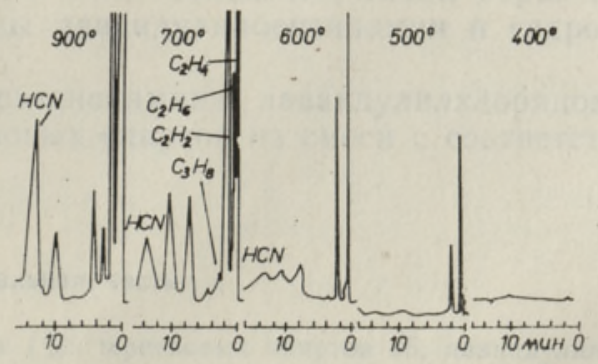

Рис. 3. Разложение кевлара при температуре от 400 до $900{ }^{\circ} \mathrm{C}$ (условия пиролиза см. рис. 1. Б). 


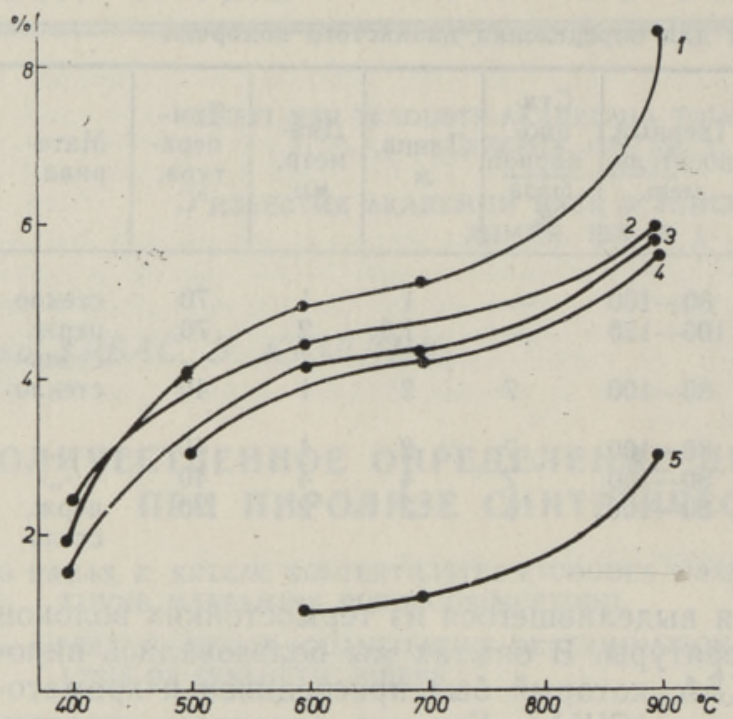

Рис. 4. Выделение $\mathrm{HCN}$ из термостойких полиакрилонитрильных волокон и номекса в зависимости от температуры пиролиза: 1 - орлон 775,2 - верел А, 3 - модакрилик СЕФ, 4 - верел $\Phi, 5$ номекс 450 .

При пиролизе полиакрилнитрила $\mathrm{HCN}$ начинает выделяться при $400^{\circ}$. Из изученных нами волокон орлон 775 дает самое большое количество HCN (при $900^{\circ} 8 \%$ от массы пробы). На рис. 4 представлены кривые выделения $\mathrm{HCN}$ из четырех видов термостойких полиакрилонитрильных волокон и из ароматического полиамидного волокна номекс.

\section{ЛИТЕРАТ У РА}

1. Щеглов П. П., Иоффе Т. А., Пенькова М. П., Мухин Б. А., Дружи н и н а Т. В. Исследование газообразного состава продуктов разложения огнезащищенных поликапроамидных волокон. - Изв. высш. учеб. заведений. Химия и хим. технология, 1974 , т. 17 , № 6 , с. $890-894$.

2. In gham, P. E. The pyrolysis of wool and the action of flame retardants. J. Appl. Polymer Sci., 1971, v. 15, p. 3025-3041.

3. К арн ишин А. А., Булыгин Б. М. Определение цианистого водорода в продуктах термодеструкции полиуретана. - Завод. лаборатория, 1973, № 9, c. $1063-1065$.

4. U r bas, E., K ülli k, E. Pyrolysis gas chromatographic analysis of some toxic compounds from nitrogen containing fibres. - J. Chromatogr., 1977, v. 137, p. $210-214$.

5. У рб а с Э. Р., К юллик Э. А. Газохроматографическое определение микроколичеств цианистого водорода. - В кн.: Материалы симпозиума «Современные методы санитарно-гигиенических исследований и применение их в практике санитарного контроля». Тарту, 1978 , с. $164-168$.

Институт химии

Академии наук Эстонской ССР
Поступила в редакцию 9/III 1978 